\title{
Impact of Corruption on Foreign Direct Investment in Africa
}

\author{
Rahim Quazi ${ }^{1}$, Vijay Vemuri ${ }^{1} \&$ Mostafa Soliman ${ }^{1}$ \\ ${ }^{1}$ College of Business, Prairie View A\&M University, Prairie View, Texas, USA \\ Correspondence: Rahim Quazi, College of Business, PO 519, MS 2300, Prairie View A\&M University, Prairie \\ View, TX 77446, USA. Tel: 1-936-261-9225. E-mail: rmquazi@pvamu.edu
}

Received: January 21, 2014

Accepted: February 2, 2014

Online Published: March 26, 2014

doi: $10.5539 /$ ibr.v7n4p1

URL: http://dx.doi.org/10.5539/ibr.v7n4p1

\begin{abstract}
A new area of research has recently emerged that analyzes the impact of corruption on foreign direct investment (FDI) in developing countries. The FDI literature comprises two opposing views of corruption - the grabbing hand hypothesis holds that corruption impedes FDI by raising uncertainty and transaction costs and the helping hand hypothesis holds that corruption facilitates FDI by greasing the wheels of commerce in the presence of weak regulatory frameworks. This study analyzes the impact of corruption on FDI inflows in 53 countries in Africa over the 1995-2012 period. Using the dynamic System Generalized Method of Moments modeling framework (Arellano-Bover/Blundell-Bond linear dynamic panel), this study finds support for the helping hand hypothesis, i.e., corruption facilitates FDI inflows in Africa. It is likely that the overall regulatory environment in Africa is weak, which helps explain the context in which the helping hand hypothesis can be validated. In addition, this study finds that past levels of FDI, market size, government effectiveness, infrastructure, and economic freedom also affect FDI significantly. These results further our knowledge of the FDI dynamics in Africa, which policymakers should find helpful in devising pro-FDI strategies.
\end{abstract}

Keywords: corruption, foreign direct investment, Africa

\section{Introduction}

Foreign direct investment (FDI) plays an important role in the growth dynamics of developing countries. FDI can fill at least three "development gaps"-first, the "investment gap" by providing capital for investment; secondly, the "foreign exchange gap" by providing foreign currency through investments and export earnings; and finally, the "tax revenue gap" by generating tax revenues through economic activities. FDI can also generate domestic investment in matching funds, facilitate transfer of technology and managerial skills, increase local market competition, create modern job opportunities, boost global market access for export commodities, etc. -all of which should ultimately contribute to economic growth in host countries. Recognizing these benefits, developing countries have generally eased restrictions on FDI since the early 1980s. In 2012, developing countries received more than half of global FDI inflows ( $\$ 703$ billion) and as many as 9 of the 20 largest FDI recipients were developing countries (World Bank, 2012).

FDI in Africa reached a peak of $\$ 72$ billion in 2008 before falling for three successive years and then rebounded back to $\$ 50$ billion in 2012. The declining trend over 2008-2011 was caused by several factors, including the onset of a global financial crisis, drop in commodity prices, and political unrest in North Africa (region that accounts for $1 / 3^{\text {rd }}$ of total FDI inflows to the continent). Given that foreign investment accounts for about $20 \%$ of Africa's gross fixed capital formation, this decline is worrisome. Despite this temporary setback, foreign investors will likely continue to invest in Africa, due to relatively high profitability. According to U.S. Department of Commerce data, U.S. FDI in Africa yielded a 20\% return in 2010, vis-à-vis 14\% return in Latin America and the Caribbean, and 15\% in Asia (UNCTAD, 2013).

In recent years, China has become the largest trade partner of Africa and one of its most prominent sources of FDI. China has now become a major investor in Sub-Saharan Africa, primarily to safeguard its access to supplies of raw materials (e.g., oil, minerals and timber). China has also invested heavily in infrastructure (e.g., roads, railroads, dams, seaports and airports) and manufacturing (e.g., textiles industry). The African Growth and Opportunity Act (AGOA) and the European Union's Everything but Arms (EBA) initiatives have granted African products special access to developed country markets, which has prompted some investors from China and other emerging countries to relocate their operations to Africa (UNCTAD, 2013). In the backdrop of these growing 
economic ties between China and Africa, a few controversies have also emerged, including fear of neo-colonization, exploitation of native workers, displacement of local jobs in light manufacturing industries and environmental degradation.

Many studies have analyzed the role of corruption as a significant determinant of economic performance and FDI in developing countries. The FDI literature comprises two competing views - the mainstream view suggests that corruption acts as a grabbing hand to reduce FDI in a number of ways. First, corruption can breed inefficiencies and distortions, which raise transaction costs for investors (Bardhan, 1997); secondly, corruption can create a risk of endangering brand goodwill in case of getting tangled up in a scandal (Zhao et al., 2003); and lastly, corruption can negatively affect other important determinants of FDI, such as economic growth (Mauro, 1995), productivity of public investment and quality of infrastructure (Tanzi \& Davoodi, 1997), and education and healthcare services (Gupta et al., 2000). The alternative view postulates that corruption can: first, serve as "speed money" that allows investors to bypass bureaucratic red tape (Huntington, 1968); secondly, expedite decision making processes and allow businesses to avoid burdensome government regulations (Lui, 1985); thirdly, help supplement low wages in developing countries, which allows their governments to keep the tax burden low, which in turn contributes to growth - an important determinant of FDI (Tullock, 1996); and lastly, "grease" the economic system in the presence of weak regulatory frameworks (Bardhan, 1997) and result in a Pareto Optimal outcome (Rashid, 1981) - all of which can facilitate FDI by extending a helping hand.

The purpose of this study is to analyze the impact of corruption on FDI inflows in Africa and test whether the empirical evidence supports the grabbing hand or helping hand hypothesis for the sample countries. The rest of the paper is organized as follows: section 2 presents a review of the empirical literature, section 3 describes the methodology, model and data, section 4 discusses the estimated results, and section 5 concludes the paper.

\section{Literature Review}

The history of corruption predates the dawn of modern civilization. Noonan (1984) has documented nearly four millennia of history of bribes and corruption in many cultures. For example, Confucius emphasized the necessity of ethical behavior to address corruption in ancient China. An inspector post was created in ancient Greece and Rome to keep market corruption under control. In ancient India, the famous philosopher and statesman Kautilya criticized the corruption of government tax collectors. In medieval era, the system of hisbah was employed in Islamic countries to control moral decay including social and economic corruption (Ketkar et al., 2005). Dante's epic poem Divine Comedy placed corrupt politicians in the fifth Bolgia of the eighth ring of Hell (Sayers, 1950). In modern era, corruption has become prevalent and entrenched in many parts of the world, particularly in developing countries.

The FDI literature comprises mixed empirical evidence about the impact of corruption on FDI. Several studies have found results that lend credence to the grabbing hand hypothesis, i.e. corruption impedes FDI inflows. Wei (2000a) analyzed different types of bilateral capital flows from 14 home countries to 53 host countries and concluded that corruption reduced FDI more than other types of capital flows. Using data on bilateral FDI flows from 12 home countries to 45 host countries, Wei (2000b) also found that corruption acted like a tax and reduced FDI. Habib and Zurawicki (2002) analyzed bilateral FDI flows from 7 home countries to 89 host countries and concluded that foreign investors are generally corruption-averse, as they view corruption as immoral and inefficient. Zhao et al. (2003) studied panel data from 40 developed and developing countries and found that corruption significantly reduced FDI inflows across geographic regions and economic classifications. Using data from 54 countries, Ketkar et al. (2005) found that a 1-point improvement in the corruption index can raise FDI by as much as $0.5 \%$ of GDP.

In contrast, several studies either found no evidence to support the grabbing hand hypothesis or found results that support the helping hand hypothesis. For example, using two different indices of corruption for a cross-section of 52 developing countries, Akcay (2001) found no evidence to support the hypothesis that corruption significantly affects FDI. Caetano and Caleiro (2005) studied FDI inflows to 97 countries and concluded that corruption significantly reduced FDI in high-corruption countries, but the impact is weak in low-corruption countries. Cuervo-Cazurra (2006) concluded that investors from relatively more corrupt home countries are more likely to invest in host countries that are also corrupt. Houston (2007) found that corruption reduced economic growth in countries with strong legal and regulatory institutions, but the opposite was found in countries with weak institutions.

A few studies have concluded that FDI is in fact affected more by other economic factors than by corruption. For example, Abed and Davoodi (2000) found that structural reforms affect FDI much more significantly than corruption in transition economies. Egger \& Winner (2006) found that corruption reduces FDI within the OECD 
countries, but FDI from the OECD block to non-OECD countries is affected more by economic growth and changes in factor endowments than by corruption. They also found that the impact of corruption vis-à-vis market growth on FDI has diminished over time.

Our search did not reveal any published research on the impact of corruption on FDI inflows in Africa, which is the central focus of this study. Although some African countries have been included in a few studies as developing countries, but no study has studied the topic exclusively for Africa. This study will make a unique contribution to the FDI literature and improve our knowledge of the FDI dynamics in Africa, which policymakers should find helpful in devising pro-FDI strategies.

\section{Methodology, Data and Estimation}

FDI models are generally grounded in the OLI (ownership, location, and internalization) paradigm developed by Dunning (1988). The ownership (O) factor addresses the "why" aspect of foreign production; the location (L) factor addresses "where" to locate foreign production; and the internalization (I) factor addresses "how" firms internalize markets. Corruption can influence the location (L) factor by affecting the locational advantage of a host country as well as the internalization (I) factor by raising transaction costs (Habib \& Zurawicki, 2002; Caetano \& Caleiro, 2005).

In line with the empirical literature, a general-to-specific modeling approach comprising the following regression equation is used (subscript $i$ refers to countries and $t$ refers to time).

$$
\begin{aligned}
& F D I_{i, t}=\alpha+\beta_{1} F I_{i, t-1}+\beta_{2} F I_{i, t-2}+\beta_{3} \text { Corruption }_{i, t}+\beta_{4} \text { Market Size }_{i, t}+\beta_{5} \text { Government Effectiveness }_{i, t} \\
& \quad+\beta_{6} \text { Infrastructure }_{i, t}+\beta_{7} \text { Economic Openness }_{i, t}+\beta_{8} \text { Economic Freedom }_{i, t}+\varepsilon_{i, t}
\end{aligned}
$$

\subsection{Model Rationale and Variable Operationalization}

The variables that have been included in the model above reflect rather broad concepts. The operationalization of these concepts and their measurement can be challenging. Next we outline how we measure these variables, noting the proxy variables we utilize if a variable is not directly available. Sources for the proxy variables and justification for their use is also noted.

FDI: It is the main variable of our interest in the study. It represents the inflows of foreign investment into a country. The model includes lagged values of the dependent variable (FDI) as regressors, which is important for several reasons. The decision makers may not instantaneously react to changes in the economic environment, i.e. there may be considerable inertia in adapting to changed circumstances. The technology may also hinder instantaneous adjustments to market changes. In addition, institutional constrains in the form of long-run contracts may make it difficult, if not impossible, to change the previous course of actions. Furthermore, foreign investors are typically risk averse and tend to avoid unfamiliar territories, which makes it important for host countries to establish a track record of attracting FDI, as that can generate a momentum for attracting additional FDI. The estimated results (presented in section 4) show that FDI exhibits considerable state dependence even after controlling for several determinants for FDI, justifying inclusion of the lagged dependent variables.

Corruption: The primary focus of this study is to analyze the impact of corruption on FDI in Africa. In line with similar FDI studies, e.g., Wei (2000a), Habib and Zurawicki (2002), Zhao et al. (2003), Voyer and Beamish (2004), Ketkar et al. (2005), and Egger and Winner (2006), this study also uses the Corruption Perceptions Index (CPI), published by the Transparency International, as a proxy measure of corruption. The CPI index is constructed with survey data to measure the perceived levels of public sector corruption in more than 170 countries (Transparency International, 2012). On this index, countries receive scores from 0 (highly corrupt) to 10 (very clean), so a lower CPI score reflects more corruption. If the estimated coefficient of the CPI index ( $\beta_{3}$ in the regression equation) turns out negative, that would indicate that lower CPI scores (i.e., more corruption) attract more FDI, which will validate the "helping hand" hypothesis. Conversely, a positive coefficient will indicate that higher CPI scores (i.e., less corruption) attract more FDI, which will support the "grabbing hand" hypothesis.

Market Size: Domestic demand in host countries can play a crucial role in attracting "market seeking" FDI, where the primary objective of multinational corporations (MNCs) is to serve the domestic market. It is possible that some FDI flowing to Africa is market-seeking in nature, which responds to the domestic market potential. Following other studies, e.g., Schneider and Frey (1985), Loree and Guisinger (1995), Jaspersen et al. (2000), Wei (2000a) and Quazi (2007), this study uses the natural log of per capita real GDP as a proxy variable for market size/potential.

Government Effectiveness: The general quality of governance in host countries can play a crucial role in either 
attracting or deterring FDI. This study uses the "Government Effectiveness" indicator, developed by the Worldwide Governance Indicators (WGI) project, as a proxy for the quality of governance. The WGI project reports governance indicators for over 200 economies for six dimensions of governance - political stability and absence of violence, voice and accountability, government effectiveness, regulatory quality, rule of law and control of corruption. The government effectiveness index is constructed from a large dataset collected from survey institutes, think tanks, NGOs and private firms. The index measures "perceptions of the quality of public services, the quality of the civil service and the degree of its independence from political pressures, the quality of policy formulation and implementation, and the credibility of the government's commitment to such policies" (WGI, 2012).

Infrastructure: Availability of infrastructure in host countries can be a critical determinant of FDI. Access to electricity, telecommunications, roads, highways, airports, seaports, etc. can increase productivity and boost the locational advantage of a host country. This study uses quality of port infrastructure as a proxy for the preparedness of a country for FDI and economic growth. Port preparedness of a country is obtained from World Economic Forum (WEF) data and measured on a scale from 1 (extremely underdeveloped) to 7 (well developed and efficient by international standards). It should be noted that not only availability, but also reliability of infrastructure (such as the frequency of power outage, etc.) is a crucial indicator of the overall quality of infrastructure, for which data is not readily available for most developing countries.

Economic Openness: Economically open countries generally pursue economic policies that are conducive to foreign trade and investment. Therefore, foreign investors typically have favorable impressions of such countries, which indicates that there should be a positive relationship between greater economic openness and FDI. Following other studies, e.g., Edwards (1990) and Gastanaga et al. (1998), economic openness is measured in this study by the share of total volume of trade (exports plus imports) in GDP.

Economic Freedom: The general quality of investment climate in host countries can play a critical role in attracting FDI. Following other studies, e.g. Quazi \& Mahmud (2006) and Quazi (2007), this study uses the Economic Freedom Index, jointly published by the Heritage Foundation and Wall Street Journal, as a proxy for domestic investment climate. The index is constructed by incorporating variables from a broad range of categories, such as government intervention in the economy, monetary policy, capital flows and foreign investment, banking and finance, property rights, etc. A country's overall index score broadly reflects the institutional setting for economic activities in that country.

\subsection{Dynamic Panel Model}

A notable feature of the regression model used in this study is that lagged values of the dependent variable (FDI) have been included as regressors. This type of dynamic panel models pose considerable challenges for estimation and inference. The combination of individual heterogeneity and the lagged dependent variables lead to serially correlated errors and consequently result in biased and inconsistent estimators (Nickell, 1981).

The modern estimation methods with dynamic panels use instrumental variables to overcome these estimation problems. Several features of dynamic panel model estimation stand out: 1) instrumental variables are generated within the system, i.e. appropriately chosen lags of dependent variables and other regressors serve as instruments (Anderson \& Hsiao, 1982). 2) The number of instruments used in each period grows with time, and with passage of time, more instruments become available (Holtz-Eakin et al., 1988). 3) The efficiency of estimation improves with additional moment conditions and important progress is made in discovering new moment conditions (Ahn \& Shmidt, 1999). 4) System Generalized Method of Moments (GMM) with optimal weighting matrix is used to improve efficiency of the estimators with dynamic panel data (Arellano \& Bond, 1991; Arellano \& Bover, 1995; Blundell \& Bond, 2000).

The software implementation of dynamic panel methods is relatively new and still evolving. This study uses optimal GMM (two-step) procedures to estimate the Arellano-Bover/Blundell-Bond linear dynamic panel regression model. For most countries, corruption perception indices did not vary much from year-to-year. We modified the corruption indices as a time invariant variable, i.e. we computed the average value of the corruption index of each country for the 18 years of data included in this study.

\subsection{Data}

This study uses 1995-2012 panel data from 53 countries in Africa. Data on FDI (annual FDI inflow as \% of GDP), market size (per capita real GDP), infrastructure (quality of port infrastructure) and economic openness (volume of trade as \% of GDP) are collected from the World Development Indicators (World Bank, 2012), government effectiveness is collected from the Worldwide Governance Indicators (WGI, 2012), economic 
freedom is collected from the Index of Economic Freedom (Heritage Foundation/Wall Street Journal, 2012), and corruption index is collected from the Corruption Perceptions Index (Transparency International, 2012).

\section{Results}

The dynamic panel estimation results are presented in Table 1 and Table 2. Heterogeneity in the model is represented by both country-specific dummy variables and year dummy variables. However, the coefficients of these variables are mostly nuisance parameters and, hence, not presented. The first four models (Table 1) do not include year dummy variables and the last four models (Table 2) do include the year dummies.

For the most part, these estimated results are in line with the a priori expected results. The impact of past FDI levels on current FDI level is positive and significant, suggesting significant positive autocorrelation or persistence/momentum. Coefficients of lagged FDI indicate strong state dependence of FDI even after controlling for economically relevant variables affecting FDI. In all eight models, the first lag of FDI turns out significant at $0.1 \%$, and more importantly, the coefficient is quite far from unity assuring that we do not have unit root problem and consequent weak instrument problem. Per capita GDP and government effectiveness have positive and significant effects on FDI. Economic openness has positive, but weak effect on FDI. The impact of infrastructure on FDI is found to be significantly negative. This apparently puzzling result can be rationalized by the fact that substantial FDI has flown to many African countries that have weak infrastructure. For example, China has invested heavily to build and upgrade infrastructure in Sub-Saharan Africa to safeguard access to supplies of raw materials. Economic freedom is also found to have a significantly negative impact on FDI, which can be rationalized by the fact that lack of economic freedom and weak regulatory frameworks go hand-in-hand, which can provide the backdrop in which the "helping hand" hypothesis is played out in Africa. The main result is that corruption in Africa has significant and positive impact on FDI inflows. In all eight models, the average corruption perception index is negatively related with FDI inflows, which suggests that lower CPI scores (i.e., more corruption) attract more FDI in Africa, which lends credence to the "helping hand" hypothesis. In five of these models, the coefficient of corruption is significant at $0.1 \%$ level; in one model, corruption is significant at $1 \%$ level, and in another model, corruption is significant at $5 \%$ level. Even in the last model, the coefficient of corruption is marginally significant with a p-value of 0.098 .

Table 1. Arellano-Bover/Blundell-Bond linear dynamic panel data estimation results

\begin{tabular}{lllll}
\hline Dependent Variable: FDI & Model 1 & Model 2 & Model 3 & Model 4 \\
\hline FDI $_{\mathrm{t}-1}$ & $0.263^{* * *}$ & $0.541^{* * *}$ & $0.526^{* * *}$ & $0.487^{* * *}$ \\
& $(0.002)$ & $(0.004)$ & $(0.010)$ & $(0.013)$ \\
FDI $_{\mathrm{t}-2}$ & $0.052^{* * *}$ & $0.023^{* * *}$ & $0.037^{* * *}$ & $0.036^{* * *}$ \\
& $(0.001)$ & $(0.005)$ & $(0.008)$ & $(0.010)$ \\
Corruption & $-1.770^{* * *}$ & $-1.712^{* * *}$ & $-2.617^{* * *}$ & $-1.303^{* *}$ \\
& $(0.092)$ & $(0.362)$ & $(0.347)$ & $(0.492)$ \\
Market Size & $0.000^{* * *}$ & $0.001 * * *$ & $0.001^{* * *}$ & $0.001^{* * *}$ \\
& $(0.000)$ & $(0.000)$ & $(0.000)$ & $(0.000)$ \\
Government Effectiveness & $0.927^{* * *}$ & 1.064 & $1.813^{*}$ & $3.018^{* *}$ \\
Infrastructure & $(0.157)$ & $(0.760)$ & $(0.811)$ & $(1.091)$ \\
& & $-1.626^{* * *}$ & $-1.694^{* * *}$ & $-1.875^{* * *}$ \\
Economic Openness & $(0.086)$ & $(0.140)$ & $(0.146)$ \\
Economic Freedom & & & $0.013^{* *}$ & 0.013 \\
\hline
\end{tabular}

Note: (Standard Errors in Parentheses) $*$ p-value $<0.05, * *$ p-value $<0.01, * * *$ p-value $<0.001$. 
Table 2. Arellano-Bover/Blundell-Bond linear dynamic panel data estimation results

\begin{tabular}{lllll}
\hline Dependent Variable: FDI & Model 5 & Model 6 & Model 7 & Model 8 \\
\hline FDI $_{\mathrm{t}-1}$ & $0.118^{* * *}$ & $0.539^{* * *}$ & $0.505^{* * *}$ & $0.474^{* * *}$ \\
& $(0.004)$ & $(0.016)$ & $(0.016)$ & $(0.020)$ \\
FDI $_{\mathrm{t}-2}$ & $-0.070^{* * *}$ & $0.029^{* *}$ & $0.021^{* * *}$ & $0.023^{*}$ \\
& $(0.003)$ & $(0.010)$ & $(0.006)$ & $(0.010)$ \\
Corruption & $-5.588^{* * *}$ & $-1.470^{*}$ & $-2.819^{* * *}$ & -1.870 \\
& $(0.873)$ & $(0.605)$ & $(0.568)$ & $(1.131)$ \\
Market Size & $0.000^{* * *}$ & $0.001^{* * *}$ & $0.001^{* * *}$ & $0.001^{* *}$ \\
& $(0.000)$ & $(0.000)$ & $(0.000)$ & $(0.000)$ \\
Government Effectiveness & $8.991^{* * *}$ & 1.184 & 0.846 & $3.949^{*}$ \\
Infrastructure & $(0.900)$ & $(1.262)$ & $(1.229)$ & $(1.971)$ \\
& & $-2.293^{* * *}$ & $-2.125^{* * *}$ & $-1.872^{* *}$ \\
Economic Openness & $(0.616)$ & $(0.642)$ & $(0.623)$ \\
Economic Freedom & & & 0.003 & 0.009 \\
\hline
\end{tabular}

Note: (Standard Errors in Parentheses) $*$ p-value $<0.05,{ }^{* *}$ p-value $<0.01, * * *$ p-value $<0.001$.

Tables 1a and 2a provide diagnostic test results for the estimated models. It is important to note that the traditional diagnostic statistics used in ordinary least squares (OLS) estimation and some of its other variations are not applicable to instrumental variable (IV) methods. It is well known that the widely used $\mathrm{R}^{2}$ statistic does not have relevance in IV models, and in fact, $\mathrm{R}^{2}$ statistic can even be negative in valid IV methods. These tables report the Wald $\chi^{2}$ statistic, which (similar to $\mathrm{R}^{2}$ ) measures the overall applicability of the model and tests the null hypothesis that all coefficients of a model are simultaneously zero. For each one of the estimated eight models, the null hypothesis is conclusively rejected, supporting the validity of these models. In most IV and GMM models, over-identification (OID) (more instruments than endogenous variables) is a prevalent feature. This can be checked with the Sargan OID test, which has a null hypothesis that OID restrictions are valid. Per the Sargan OID statistic reported in the tables, the null hypothesis of valid OID restrictions is not rejected for any model, which again supports the validity of these models. As a final check, we test the applicability of the Sargan test to our models. As Arellano \& Bond (1991) have pointed out, moment conditions of a GMM model are valid only if idiosyncratic errors of the model have no serial correlation. The null hypothesis of the Arellano-Bond serial correlation test is that moment conditions used in the model are valid. The Arellano-Bond test statistics reported in the tables show that the null hypothesis is not rejected for any model, which supports the validity of the Sargan OID test used.

This study finds support for the helping hand hypothesis, i.e. corruption affects FDI inflows in Africa positively, which is not very surprising. After all, bribes can make it easy for a foreign investing company to navigate complex bureaucratic regulations of host countries. Cynics view that the foreign operations by developed countries in developing countries can only be accomplished by bribery and adopting to local customs, that may involve rampant corrupt practices, which is not limited to Africa by any means. The recent rapid growth of operations of Walmart, Inc. in Mexico and accusations of involvement of Walmart, Inc. in bribery and other corrupt practices suggest that corporations of developed countries may benefit from corrupt practices of host countries anywhere in the world (Barstow \& Von Bertrab, 2012). 
Table 1a. Diagnostic tests for estimation results in Table 1

\begin{tabular}{|c|c|c|c|c|c|c|c|c|c|}
\hline \multirow{2}{*}{ Model } & \multicolumn{3}{|c|}{ Wald $\chi^{2}$ Test } & \multicolumn{3}{|c|}{ Sargan OID Test } & \multicolumn{3}{|c|}{ Arellano-Bond Serial Correlation Test } \\
\hline & Statistic & d.f. & p-value & Statistic & d.f. & p-value & Lags & Statistic & p-value \\
\hline \multirow[t]{2}{*}{1} & 81053.25 & 5 & 0.00 & 49.01 & 108 & 1 & Lag 1 & -1.58 & 0.11 \\
\hline & & & & & & & Lag 2 & 0.27 & 0.79 \\
\hline \multirow[t]{2}{*}{2} & 105380.1 & 6 & 0.00 & 27.70 & 56 & 1 & Lag 1 & -1.55 & 0.12 \\
\hline & & & & & & & Lag 2 & -0.18 & 0.85 \\
\hline \multirow[t]{2}{*}{3} & 15394.97 & 7 & 0.00 & 24.80 & 56 & 1 & Lag 1 & -1.48 & 0.14 \\
\hline & & & & & & & Lag 2 & -0.29 & 0.78 \\
\hline \multirow[t]{2}{*}{4} & 21753.83 & 8 & 0.00 & 19.36 & 56 & 1 & Lag 1 & -1.63 & 0.10 \\
\hline & & & & & & & Lag 2 & -0.30 & 0.76 \\
\hline
\end{tabular}

Table 2a. Diagnostic tests for estimation results in Table 2

\begin{tabular}{|c|c|c|c|c|c|c|c|c|c|}
\hline \multirow{2}{*}{ Model } & \multicolumn{3}{|l|}{ Wald $\chi^{2}$ Test } & \multicolumn{3}{|c|}{ Sargan OID Test } & \multicolumn{3}{|c|}{ Arellano-Bond Serial Correlation Test } \\
\hline & Statistic & d.f. & p-value & Statistic & d.f. & p-value & Lags & Statistic & p-value \\
\hline \multirow[t]{2}{*}{5} & 430836.81 & 16 & 0.00 & 45.09 & 106 & 1 & Lag 1 & -1.60 & 0.11 \\
\hline & & & & & & & Lag 2 & 0.91 & 0.36 \\
\hline \multirow[t]{2}{*}{6} & 13909.05 & 10 & 0.00 & 26.80 & 56 & 1 & Lag 1 & -1.53 & 0.13 \\
\hline & & & & & & & Lag 2 & -0.24 & 0.81 \\
\hline \multirow[t]{2}{*}{7} & $1.01 \mathrm{E}+06$ & 11 & 0.00 & 30.89 & 56 & 1 & Lag 1 & -1.50 & 0.13 \\
\hline & & & & & & & Lag 2 & 0.26 & 0.80 \\
\hline \multirow[t]{2}{*}{8} & 94605.93 & 12 & 0.00 & 22.51 & 56 & 1 & Lag 1 & -1.57 & 0.12 \\
\hline & & & & & & & Lag 2 & -0.27 & 0.79 \\
\hline
\end{tabular}

\section{Conclusions}

This study uses the dynamic panel regression modeling methodology on 1995-2012 data from 53 African countries to investigate the role of corruption on FDI. The estimated results suggest that corruption positively affects FDI inflows to Africa, which validates the helping hand hypothesis that corruption "greases" the wheels of commerce in the presence of weak regulatory frameworks and facilitates FDI. However, as Africa's weak regulatory environment improves over time and eventually catches up with other regions, the corruption-FDI relationship may follow the same negative pattern as found in other regions. In other words, the helping hand of corruption in Africa may in time degenerate into the grabbing hand of corruption. Other results estimated in this study suggest that foreign investors' incremental familiarity with host economies, larger market size/potential, and higher government effectiveness can significantly boost FDI inflows. While these results are generally consistent with the current FDI literature, however finding corruption a robust and significantly positive determinant of FDI in Africa is a noteworthy contribution to the literature. An important underlying assumption of the helping hand hypothesis is the presence of a weak regulatory environment in the FDI recipient countries. This study did not explicitly investigate whether the overall regulatory environment in Africa is indeed weak vis-à-vis other regions, which is an avenue of further research.

Foreign investors' incremental knowledge about African countries is found to significantly increase the current level of FDI, which suggests that if a host country is able to successfully attract FDI initially, that will boost foreign investors' confidence in investing in that country, which in turn will open the door to additional FDI inflows. Since the level of FDI is not a policy instrument for African countries, they should utilize the available pro-FDI policy instruments to dispel the risk-averse new foreign investors' fear of committing initial investment in Africa. Greater market size/potential, measured by per capita real income, is also found to attract more FDI. Since per capita real income is affected by economic growth, government strategies to attract FDI should also include pro-growth economic policies, which per se is a desirable outcome. Higher government effectiveness 
can also have positive impact on FDI, which African policymakers should take into account when designing long-term strategies to enhance the locational appeal of their countries to foreign investors. A better knowledge of these economic fundamental is crucial for devising strategies to not only attract more FDI in the short run, but also to promote long-term economic development - a course that holds much at stake for Africa.

\section{Acknowledgements}

This study is funded by a research grant from the College of Business, Prairie View A\&M University, Prairie View, Texas, USA.

\section{References}

Abed, G., \& Davoodi, H. (2000). Corruption, Structural Reforms, and Economic Performance in the Transition Economies. IMF Working Paper, no. 00/132. Washington, DC: International Monetary Fund.

Ahn, S. C., \& Schmidt, P. (1999). Modified Generalized Instrumental Variables Estimation of Panel Data Models with Strictly Exogenous Instrumental Variables. Chapter 7. In C. Hsiao, K. Lahiri, L. F. Lee \& M. H. Pesaran (Eds.), Analysis of Panels and Limited Dependent Variable Models (pp. 171-198). Cambridge: Cambridge University Press. http://dx.doi.org/10.1017/CBO9780511493140.009

Akcay, S. (2001). Is Corruption an Obstacle for Foreign Investors in Developing Countries? A Cross-Country Evidence. Yapi Kredi Economic Review, 12(2), 27-34.

Anderson, T. W., \& Hsiao, C. (1982). Formulation and Estimation of Dynamic Models Using Panel Data. Journal of Econometrics, 18, 47-82. http://dx.doi.org/10.1016/0304-4076(82)90095-1

Arellano, M., \& Bond, S. (1991). Some Tests of Specification for Panel Data: Monte Carlo Evidence and an Application to Employment Equations. Review of Economic Studies, 58, 277-297. http://dx.doi.org/10.2307/2297968

Arellano, M., \& Bover, O. (1995). Another Look at the Instrumental Variables Estimation of Error Component Models. Journal of Econometrics, 68, 29-51. http://dx.doi.org/10.1016/0304-4076(94)01642-D

Bardhan, P. (1997). Corruption and Development: A Review of Issues. Journal of Economic Literature, 35(3), $1320-1346$.

Barstow, D., \& Von Bertrab, A. X. (2012, December 17). The Bribery Aisle: How Wal-Mart Got Its Way In Mexico. New York Times.

Blundell, R., \& Bond, S. (2000). GMM Estimation with Persistent Panel Data: An Application to Production Functions. Econometric Reviews, 19, 321-340. http://dx.doi.org/10.1080/07474930008800475

Caetano, J., \& Caleiro, A. (2005). Corruption and Foreign Direct Investment: What kind of relationship is there? University of Évora, Economics Working Papers, no. 18_2005.

Cuervo-Cazurra, A. (2006). Who cares about corruption? Journal of International Business Studies, 37, 807-822. http://dx.doi.org/10.1057/palgrave.jibs.8400223

Dunning, J. (1988). The Eclectic Paradigm of International Production: A Restatement and Some Possible Extensions. Journal of International Business Studies, 19(1), 1-31. http://dx.doi.org/10.1057/palgrave.jibs. 8490372

Edwards, S. (1990). Capital Flows, Foreign Direct Investment, and Debt-Equity Swaps in Developing Countries. NBER Working Paper, no. 3497.

Egger, P., \& Winner, H. (2006). How Corruption Influences Foreign Direct Investment: A Panel Data Study. Economic Development and Cultural Change, 54(2), 459-486. http://dx.doi.org/10.1086/497010

Gastanaga, V., Nugent, J., \& Pashamiova, B. (1998). Host Country Reforms and FDI Inflows: How Much Difference Do They Make? World Development, 26, 1299-1314. http://dx.doi.org/10.1016/S0305-750X(98)00049-7

Gupta, S., Davoodi, H., \& Tiongson, E. (2000). Corruption and the Provision of Health Care and Education Services. IMF Working Paper, Vol. 00/116.

Habib, M., \& Zurawicki, L. (2002). Corruption and Foreign Direct Investment. Journal of International Business Studies, 33(2), 291-307. http://dx.doi.org/10.1057/palgrave.jibs.8491017

Heritage Foundation/Wall Street Journal. (2012). Index of Economic Freedom. Washington, DC: The Heritage Foundation. 
Holtz-Eakin, D., Newey, W., \& Rosen, H. S. (1988). Estimating Vector Autoregressions with Panel Data. Econometrica, 56, 1371-1395. http://dx.doi.org/10.2307/1913103

Houston, D. (2007). Can Corruption Ever Improve an Economy? Cato Journal, 27(3), 325-342.

Huntington, S. (1968). Political Order in Changing Societies. New Haven, CT: Yale University Press.

Jaspersen, F., Aylward, A., \& Knox, A. (2000). The Effects of Risk on Private Investment: Africa Compared with Other Developing Areas. In P. Collier \& C. Pattillo (Eds.), Investment and Risk in Africa (pp. 71-95). New York: St. Martin's Press.

Ketkar, K., Murtuza, A., \& Ketkar, S. (2005). Impact of Corruption of Foreign Direct Investment and Tax Revenues. Journal of Public Budgeting Accounting and Financial Management, 17(3), 313-340.

Loree, D., \& Guisinger, S. (1995). Policy and Non-policy Determinants of US Equity Foreign Direct Investment. Journal of Business Studies, 26(2), 281-299. http://dx.doi.org/10.1057/palgrave.jibs.8490174

Lui, F. (1985). An Equilibrium Queuing Model of Bribery. Journal of Political Economy, 93(4), 760-781. http://dx.doi.org/10.1086/261329

Mauro, P. (1995). Corruption and Growth. The Quarterly Journal of Economics, 110(3), 681-712. http://dx.doi.org/10.2307/2946696

Nickell, S. (1981). Biases in Dynamic Models with Fixed Effects. Econometrica, 49, 1417-1426. http://dx.doi.org/10.2307/1911408

Noonan, J. T. (1984). Bribes. Berkeley, CA: University of California Press.

Quazi, R. (2007). Economic Freedom and Foreign Direct Investment in East Asia. Journal of the Asia Pacific Economy, 12(3), 329-344. http://dx.doi.org/10.1080/13547860701405755

Quazi, R., \& Mahmud, M. (2006). Determinants of Foreign Direct Investment in South Asia. The International Journal of Business and Public Administration, 3(1), 1-13.

Rashid, S. (1981). Public Utilities in Egalitarian LDC's: The Role of Bribery in Achieving Pareto Efficiency. Kyklos, 34, 448-460. http://dx.doi.org/10.1111/j.1467-6435.1981.tb01199.x

Sayers, D. L. (translator) (reprint edition 1950). Dante Alighieri: The Divine Comedy, Part I: Hell. Penguin Classics.

Schneider, F., \& Frey, B. (1985). Economic and Political Determinants of Foreign Direct Investment. World Development, 13(2), 161-175. http://dx.doi.org/10.1016/0305-750X(85)90002-6

Tanzi, V., \& Davoodi, H. (1997). Corruption, Public Investment, and Growth. IMF Working Paper, Vol. 97/139, $1-23$.

Transparency International. (2012). Corruption Perceptions Index. Retrieved on January 5, 2014, from http://www.transparency.org/policy_research/surveys_indices/cpi/2012

Tullock, G. (1996). Corruption Theory and Practice. Contemporary Economic Policy, 14, 6-13. http://dx.doi.org/10.1111/j.1465-7287.1996.tb00619.x

UNCTAD. (2013). World Investment Report 2013. Geneva: United Nations.

Voyer, P., \& Beamish, P. (2004). The Effect of Corruption on Japanese Foreign Direct Investment. Journal of Business Ethics, 50(3), 211-224. http://dx.doi.org/10.1023/B:BUSI.0000024737.57926.bf

Wei, S. (2000a). How Taxing Is Corruption on International Investors? Review of Economics and Statistics, 82(1), 1-11. http://dx.doi.org/10.1162/003465300558533

Wei, S. (2000b). Local Corruption and Global Capital Flows. Brookings Papers on Economic Activity, 2, 303-346. http://dx.doi.org/10.1353/eca.2000.0021

World Bank. (2012). World Development Indicators. CD-ROM, World Bank, Washington, DC.

Worldwide Governance Indicators. (2012). Retrieved on January 5, 2014, from http://info.worldbank.org/governance/wgi/index.aspx\#home

Zhao, J., Kim, S., \& Du, J. (2003). The Impact of Corruption and Transparency on Foreign Direct Investment: An Empirical Analysis. Management International Review, 43(1), 41-62. 


\section{Copyrights}

Copyright for this article is retained by the author(s), with first publication rights granted to the journal.

This is an open-access article distributed under the terms and conditions of the Creative Commons Attribution license (http://creativecommons.org/licenses/by/3.0/). 